\title{
Cutaneous Drug Reactions Associated With Nivolumab Treatment for Metastatic Non-Small- Cell Lung Cancer (Nsclc) Case Report
}

\section{Adrián Pablo Huñis*, Dra Gabriela Nacuzzi, Martín Pitzzu, Dra Melisa Huñis, Laura Juffé and Sergio Lepoivre} Buenos Aires Oncology Center (COBA), Argentina

Submission: April 01, 2018; Published: April 16, 2018

"Correspondence Address: Adrián Pablo Huñis, Buenos Aires Oncology Center (COBA) Affiliated Institution of the Faculty of Medicine UBA, H Yrigoyen 4221, Buenos Aires, Argentina, Email: aphunis@gmail.com

\begin{abstract}
We present the clinical case of a patient diagnosed with non-small cell lung cancer (NSCLC) under treatment with Nivolumab. The patient develops a severe dermatological condition, which is why a biopsy of one of the lesions is performed, the diagnosis being: "Cutaneous Drug Reactions". We review the literature, discuss the mechanisms by which these clinical presentations can occur and present this patient as a contribution to the medical literature on the adverse effects by this molecule.
\end{abstract}

\section{Introduction}

Nivolumab is a humanized IgG4 monoclonal antibody which binds to the programmed death 1 (PD-1) receptor and blocks its interaction between PD-L1 and PD-L2. It has been approved in various neoplasic treatments; metastatic non-small-cell lung cancer among some of them. The negative regulator of $\mathrm{T}$ cell activation is inhibited during the PD-1 blocking. Therefore, significant responses are obtained and antitumor activity is promoted [1]. This treatment has a high level of tolerability. However, it is associated with different immune system toxicities such as a range of adverse cutaneous reactions. The most frequent is approximately $10 \%$ rash in NSCLC patients [2-5]. The authors' objective is to describe a cutaneous drug reaction case associated with nivolumab treatment in a non-small-cell lung cancer patient.

\section{Case Report}

Seventy seven-year-old male patient diagnosed in 2013 with epidermoid NSCLC, nonmutant EGFR negative ALK, negative ROS1 and PDL1 < 1\%, initial stage III (T3N1M0). He had received previous systemic treatment with chemotherapy (carboplatin and paclitaxel regimen in neoadjuvant context and docetaxel for local progression) since March 2017 under treatment with Nivolumab 3mg/kg every 14 days due to mediastinal relapse, partial response to the treatment. In January 2018 (10-month treatment with anti PD1) the patient consults due to 48-72 hours of symptoms characterized by a confluent maculopapular exanthem (morbilliform) Grade 2 (CTCAE version 4.0), slightly pruriginous, which affects face, trunk and both upper limbs with symmetrical distribution, with a tendency to confluent (Figure 1). No altered mucous or systemic symptoms.

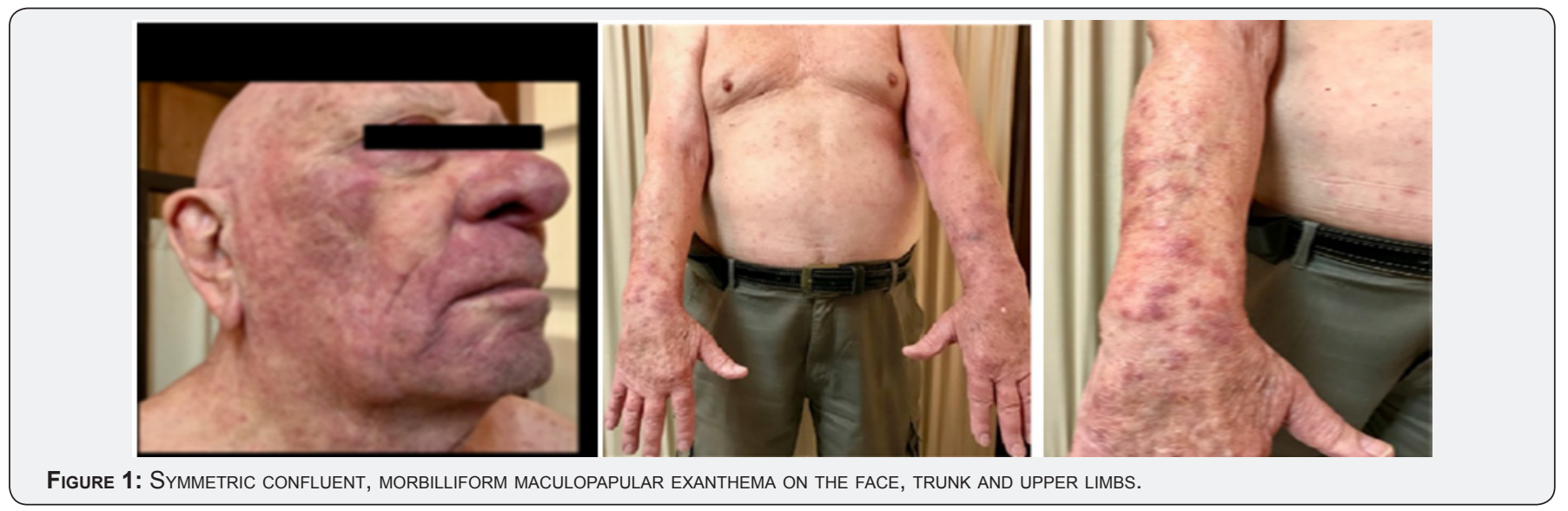




\section{Cancer Therapy \& Oncology International Journal}

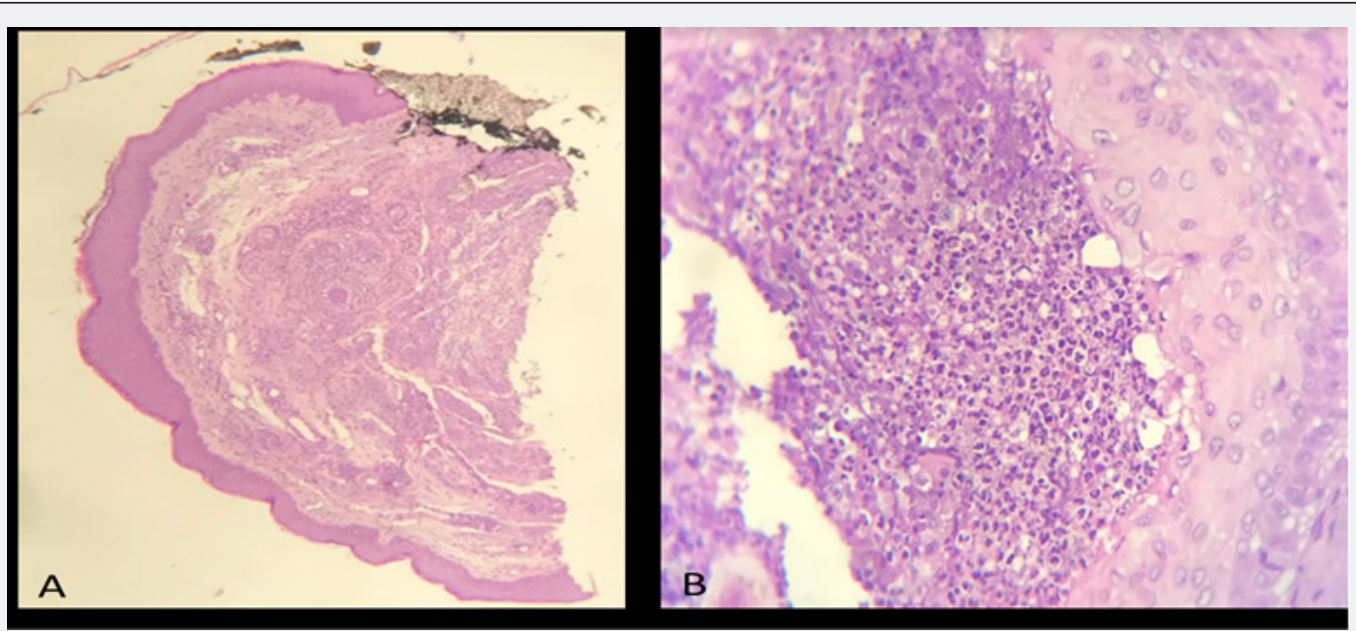

FIGURE 2:

A. 10X. H\&E EPIDERMIS WITH ORTHOKERATOSIS, DERMIC EDEMA WITH SUPERFICIAL PERIVASCULAR MIXED INFLAMMATORY INFILTRATE, ERYTHROCYTE EXTRAVASATION AND SUPPURATIVE FOLLICULITIS.

B. Suppurative folliculitis. 40x H\&E.

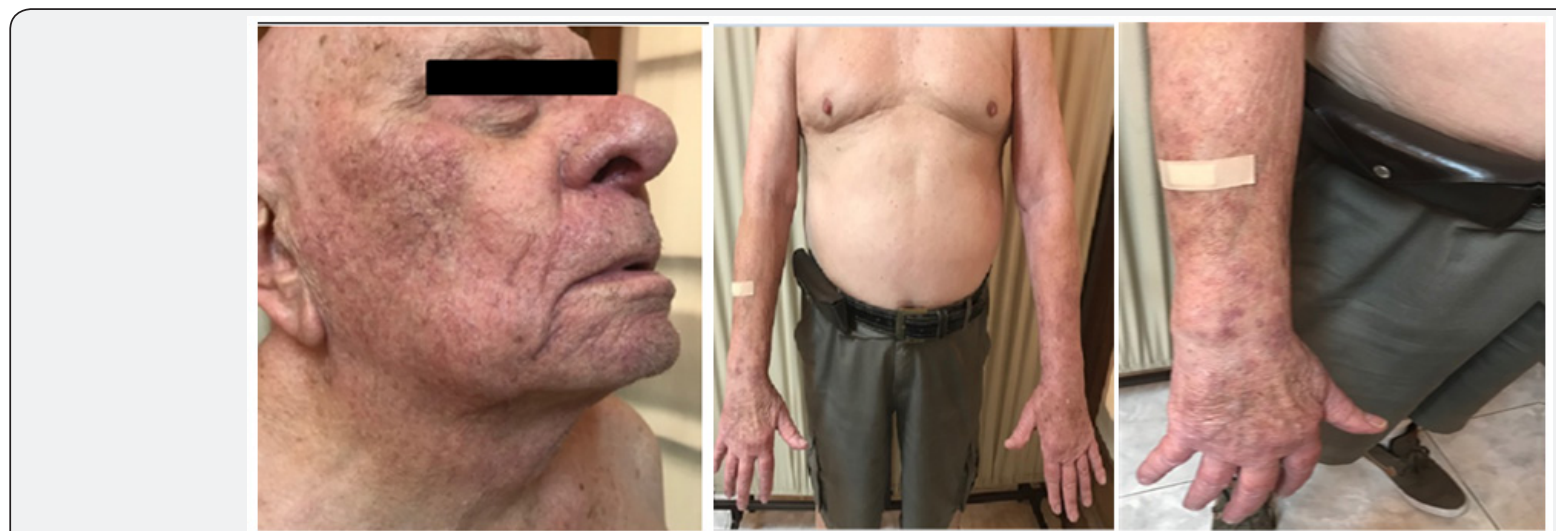

FigurE 3: EXANTHEM AFTER ONE WEEK CORTICOID TREATMENT.

Complete laboratory test with no results to outline. Skin biopsy is performed (right arm). It reveals (363711 Histopathology Protocol, L.J. Doctor) dermis with marked edema, superficial perivascular mixed inflammatory infiltrate with scattered eosinophils, erythrocyte extravasation and suppurative folliculitis, Histology connected to cutaneous drug reactions (Figure 2). Infusion of nivolumab is discontinued and the patient begins corticotherapy treatment (deltisone b $20 \mathrm{mg}$ per day). After a week under corticoids, a significant recovery of the exanthem (Figures $2 \& 3$ ) with partial resolution is observed. Corticotherapy is continued with a weekly reduced dose. Objective response occurred and the patient starts nivolumab infusion with no need for dose reduction.

\section{Discussion}

Immune-mediated adverse reactions during immunotherapy treatment can affect different organs as a consequence of upregulation of immune response [6]. Within all adverse reactions of anti PD1 reported, the skin is one of the affected organs. Rash and pruritus have been reported in approximately 10\% 2-34 in NSCLC patients treated with nivolumab. This percentage is higher in patients with melanoma treated with this same drug, approximately 28-36\% [7-9]. Management of immunemediated skin adverse reactions include antihistamines and topic corticotherapy and, according to severity, the need for systemic immunosuppression10. Within the cutaneous reactions described under nivolumab treatment, pruritus, vitiligo rash, alopecia and reactions in the injection area can be found $[5,11,12]$.

Most of them in the melanoma treatment. However, cases of exacerbation of pre-existing psoriasis have been reported [13] and even a case of Steven Johnson syndrome in the NSCLC treatment [14]. Even though cutaneous toxicity is a common effect in anti PD1 therapy, there is limited information and reports about characterization and classification of skin adverse reactions [15]. Moreover, pathophysiological mechanisms that regulate the dermatological toxicity are mostly unknown. Given the mechanism of action of nivolumab, which acts as an immunomodulatory, it is expected that by this immunity activation an unusual finding of antigens in activated dermis/ epidermis would be observed. 
An inflammatory action would be generated. However, the specific mechanisms that drives the $\mathrm{T}$ cells to the skin causing different types of dermatological toxicity haven't been identified yet [16-18]. In our case, the cutaneous toxicity was manifested by a morbilliform pruriginous maculopapular exanthem on face, trunk and limbs. The histopathology confirmed grade 2 cutaneous drug reactions, with ad integrum resolution subsequent to systemic corticoid treatment. We report this case to contribute to the international literature on cutaneous drug reactions caused by nivolumab in NSCLC treatment. Additional research is needed to gain more knowledge about the characterization and classification of the specific cutaneous toxicities caused by nivolumab and to determine if any particular skin reaction might be a predictive response factor to the undergoing therapy.

\section{References}

1. Gettinger SN, Horn L, Gandhi L, Spigel DR, Antonia SJ, et al. (2015) Overall survival and long-term safety of nivolumab(anti- programmeddeath 1 antibody, BMS936558,0NO-4538) in patients with previously treated advanced non-small-cell lung cancer. J Clin Oncol 33(18): 2004- 2012.

2. Borghaei H, Paz-Ares L, Horn L, Spigel DR, Steins M, et al. (2015) Nivolumab versus docetaxel in advanced nonsquamous non-small-cell lung cancer. New Engl J Med 373: 1627-1639.

3. Topalian SL, Hodi FS, Brahmer JR, Gettinger SN, Smith DC, et al. (2012) Safety, activity, and immune correlates of anti-PD-1 antibody in cancer New Engl J Med 366: 2443-2454.

4. Goldinger SM, Stieger P, Meier B, Micaletto S, Contassot E, et al. (2016) Cytotoxic cutaneous adverse drug reactions during anti-PD-1 therapy. Clin Cancer Res 22: 4023-4029.

5. Rizvi NA, Mazieres J, Planchard D, Stinchcombe TE, Dy GK, et al. (2015) Activity and safety of nivolumab, an anti-PD-1 immune checkpoint inhibitor, for patients with advanced, refractory squamous non-smallcell lung cancer (CheckMate 063): a phase 2, single-arm trial. Lancet Oncol 16(3): 257-265.

6. Hofmann L, Forschner A, Loquai C, Goldinger SM, Zimmer L, et al. (2016) Cutaneous, gastrointestinal, hepatic, endocrine, and renal sideeffects of anti-PD-1 therapy. Eur J Cancer 60: 190-209.

7. Robert C, Long GV, Brady B, Dutriaux C, Maio M, et al. (2015) Nivolumab in previously untreated melanoma without BRAF mutation. New Engl Med 372: 320-330.

8. Weber JS, D Angelo SP, Minor D, Hodi FS, Gutzmer R, et al. (2015) Nivolumab versus chemotherapy in patients with advanced melanoma who progressed after anti-CTLA-4 treatment (CheckMate 037): a randomised, controlled, open-label, phase 3 trial. Lancet Oncol 16: 375-384.

9. Goldinger SM, Stieger P, Meier B, Micaletto S, Contassot E, et al. (2016) Cytotoxic cutaneous adverse drug reactions during anti-PD-1 therapy. Clin Cancer Res 22(16): 4023-4029.

10. Spain L, Diem S, Larkin J (2016) Management of toxicities of immune checkpoint inhibitors. Cancer Treat Rev 44: 51-60.

11. Weber JS, Kudchadkar RR, Yu B (2013) Safety, efficacy, and biomarkers of nivolumab with vaccine in ipilimumab-refractory or -naive melanoma. J Clin Oncol 31(34): 4311-4318.

12. Topalian SL, Hodi FS, Brahmer JR, Scott N Gettinger, David C Smith, et al. (2012) Safety, activity, and immune correlates of anti-PD-1 antibody in cancer. N Engl J Med 366: 2443-2454.

13. Tracey N Liebman, Lauren Adams, Usha Alapati (2017) Palmoplantar exacerbation of psoriasis after nivolumab for lung cáncer JCSO (15)2: 106-108.

14. Salati M, Pifferi M, Baldessari C, Bertolini F, Tomasello C, et al. (2018) Stevens-Johnson syndrome during nivolumab treatment of NSCLC. Annals of Oncology 29(1): 283-284.

15. Topalian SL, Sznol M, McDermott DF, Kluger HM, Carvajal RD, et al. (2014) Survival, durable tumor remission, and long-term safety in patients with advanced melanoma receiving nivolumab. J Clin Oncol 32(10): 1020-1030.

16. Abdel-Rahman O, El Halawani H, Fouad M (2015) Risk of cutaneous toxicities in patients with solid tumors treated with immune checkpoint inhibitors: a meta-analysis. Future Oncol 11(17): 2471-2484.

17. Ciccarese C, Alfieri S, Santoni M, Santini D, Brunelli M, et al. (2015): New toxicity profile for novel immunotherapy agents: focus on immune-checkpoint inhibitors. Expert Opinion on Drug Metabolism \& Toxicology 12(1): 57-75.

18. Sibaud V, Meyer N, Lamant L (2016) Dermatologic complications of anti-PD-1/PD-L1 immune checkpoint antibodies. Curr Opin Oncol 28(4): 254-263.

\section{Your next submission with Juniper Publishers} will reach you the below assets

- Quality Editorial service

- Swift Peer Review

- Reprints availability

- E-prints Service

- Manuscript Podcast for convenient understanding

- Global attainment for your research

- Manuscript accessibility in different formats

( Pdf, E-pub, Full Text, Audio)

- Unceasing customer service

Track the below URL for one-step submission https://juniperpublishers.com/online-submission.php 